\title{
Research on the announcement effect of second equity offerings? An quantitative analysis of Chinese infrastructure companies
}

\author{
Ziyi Zhang ${ }^{1}$ \\ ${ }^{1}$ College of Civil Engineering, Oregon State University Corvallis, Oregon, 97330, United States
}

\begin{abstract}
Many issues have emerged currently regarding refinancing as a main financing source of Chinese listed companies. This study aims to identify key factors that influence the announcement effect of second equity offerings (SEOs) with 110 infrastructure companies listed on A-share stock market. By building a multivariate regression model, this study analyzed the influence factors from the perspective of the company's fundamentals and the characteristics of refinancing, and found that the company's fundamentals have same impact on the announcement effect. Return on equity, net profit margin and debt-to-equity ratio are all positively related to the accumulated abnormal return. The market pays more attention to the profitability when talking about SEOs. As to the characteristics of refinancing, the dilute ratio and the relative issuing scale have little impact on the announcement effect but the market does concern about the purpose of fund-raising.
\end{abstract}

\section{Introduction}

With the rapid urbanization in the context of China, there exists severe fiscal problems of local government which are induced by increasing public infrastructure investment. To solve this problem, it would be helpful to raise money through Initial Public Offerings (IPOs). However, equity refinancing (i.e. SEOs) is the most common refinancing channel in China, which is contrary to relevant theory of capital structure raised by many scholars[1-3] who claim that equity refinancing is worse than debt refinancing, which show a bad signal of corporation performance in the future to the market. Therefore, it would be meaningful to detect the influence factors of equity refinancing announcement effect. The refinancing announcement effect refers to the significant positive or negative change of the stock price in the short-term (several trading days before and after the announcement) after the listed company announces the refinancing information to the market. This effect is mainly characterized by abnormal returns from stock price changes, usually measured by event study methodology. This study constructed a more comprehensive and systematic classification of infrastructure companies based on the definition of general industry classification criteria, and identified 110 infrastructure companies listed on A-share stock market.

The remainder of this paper is revealed as follows. Section 2 reviews the existing literature focusing on the relation between SEOs and announcement effect of the company. Section 3 proposes relevant hypothesis and underlying inference. Section 4 shows fitness and selection of regression models and discusses empirical results. Section 5 illustrates conclusions of this study.

\section{Literature review}

A vast majority of studies have focused on the relation between equity refinancing and announcement effect based on the traditional corporate finance theory. Asquith and Mullins (1986) selected companies listed on the New York Stock Exchange from 1963 to 1981 as the sample[4]. The cumulative abnormal return rate of industrial stocks in the event window $(-1,0)$ is $-2.7 \%$. The cumulative abnormal return rate of public infrastructure stocks in the event window $(-1,0)$ is $-0.9 \%$. They believe that the reason for the weak announcement effect of utility stocks is not very clear. The likely reason is that since the financial leverage of the public infrastructure company is regulated and basically remains relatively stable, the change in financial leverage caused by the issuance of stocks is temporary. It is partially predictable that public infrastructure companies invest to meet public needs, which is related to local population growth. Therefore, the market recognizes these two points, which make the negative reaction of the market after the announcement much smaller. Masulis and Korwar (1986) used the issuance of new shares of listed companies from 1963 to 1980 as samples, and the cumulative abnormal returns ($3.25 \%$ ) of industrial stocks in the event window were greater than the cumulative abnormal returns of utility stocks $(-0.68 \%)$ [5]. They believe that in addition to being partially predictable in relation to the refinancing of public infrastructure companies, the frequent refinancing has also made the market's response to the incident dull. Sant and Ferris (1994) conducted an event study on the announcement of the stock price response in the posttransaction day and the announcement effect of the 
issuance of new shares by all-equity firms, which found a negative cumulative abnormal return[6].

Moreover, some scholars have conducted empirical research to correct previous empirical research errors or to verify theories that have not been empirically tested in the past. For example, Booth and Chang (2011) found that the market pays for the relationship between the company's dividend payment and the abnormal earnings of the public announcement date[7]. Kato and Suzuki (2012) validated the Divergence of Opinion with Japan's unique distribution method, arguing that the greater the divergence of views on a stock, the greater the slope of the stock demand curve[8]. Chaudhuri and Seo (2012) used the company data of the "Duel Class" in the United States to examine the impact of the separation of voting rights and cash rights on the public announcement effect of listed companies and the long-term performance[9].

As to the studies mentioned above, it can clearly show that the impact of equity refinancing on stock prices within event window has been well studied. However, the research gap is that most of previous studies have not considered the influence factors of equity refinancing announcement effect.

\section{Hypothesis}

According to the definition of public infrastructure and the general industry classification criteria, nine secondary industries (i.e., railway, bus, highway, airport, port, electricity, water, gas and environmental protection), including 134 infrastructure listed companies to construct the sample. And by discarding 14 companies which are listed in the small and medium board or growth enterprise market and 10 companies whose main business income is not from the public infrastructure industry, 110 companies are selected in the sample.

This paper finds the factors that affect the refinancing announcements effects, which can be mainly drawn from the characteristics of the company and the characteristics of the refinancing vehicle itself. Therefore, most previous research takes abnormal income in the event window as the proxy variable of the announcement effect, and takes cumulative abnormal returns in the statistically significant event window as the dependent variable. This study also follows this principle, and selects the cumulative abnormal return in the event window with the highest level of significance as the dependent variable. For SEOs, the dependent variable is defined as the cumulative abnormal return within event window $(-1,1)$. According to the section of literature review, the hypothesis are as follows.

H1: A larger company accompanies with a greater degree of information asymmetry, which lower the investor's trust in refinancing and lower the cumulative abnormal return before and after the announcement date. Therefore, the company size is inversely related to the refinancing announcement effect. In this study, the company size SIZE is calculated by multiplying the total number of shares of the listed company before refinancing by the average of the closing price of the 30 trading days before the refinancing event of the listed company. In order to make the data smoother, we take the natural logarithm of the company's scale, and finally enter the regression equation with the variable LNSIZE.

H2: High financial leverage will make the company more profitable ceteris paribus, and the cumulative abnormal returns before and after the announcement day will be greater. Therefore, financial leverage is positively related to the refinancing announcement effect. This study uses the asset-liability ratio DEBT (i.e., the ratio of liabilities to assets) as the proxy variable for financial leverage, which is based on the annual report of the year before listed company refinancing.

H3: Companies with strong profitability can increase the value of the company through refinancing, thereby increasing the value of the investor's equity. The cumulative abnormal returns before and after the announcement date should be higher. Therefore, profitability is positively related to the refinancing announcement effect. For the announcement effect of equity refinancing, the ROE indicator is adopted to reflect the return rate obtained by the investor as a shareholder who cares about the equity value. For the announcement effect of issuing bonds, the sales net interest rate NSPM (i.e., the ratio of net profit to sales revenue) is directly used to reflect the return rate obtained by investors as creditors who care about corporate value.

H4: Increasing the supply of stocks will put pressure on the stock price. The greater the proportion of additional issuance, the lower the cumulative abnormal return before and after the announcement date[10]. Therefore, the proportion of additional issuance is negatively related to the announcement effect of equity refinancing. Among them, the issuance ratio DILUTE is equal to the ratio of the proposed additional share capital to the total share capital before the issuance.

H5: motivation "circle money" is negatively related to the announcement effect of equity refinancing. This study constructs a dummy variable OBJECTIVE that reflects the use of raised funds. According to the sample to issue an Ashare prospectus, if the description of the use of funds has "supplementary liquidity" or "permanent replenishment of working capital”, OBJECTIVE takes 1 and vice versa, 0 .

Therefore, interpretation model of announcement effect I is shown as follows,

$C A R(-1,1)=\alpha+\beta_{1} L N S I Z E+\beta_{2} D E B T+\beta_{3} R O E+\beta_{4} D I U I E+\beta_{5} O B J E C T I V E$

\section{Empirically analysis}

Multivariate regression analysis of model I is performed using Eviews6. The OLS (ordinary least squares) method is used and the best fitting equation is selected by backward elimination. The results are shown in Table 1 . Model 3 is used as the optimal fit model, and the model's ability to interpret the cumulative abnormal returns is $43.45 \%$.

Table1. Announcement effect of equity refinancing.

\begin{tabular}{ccccccc}
\hline Independent variableCoefficient (Model 1) t-value Coefficient (Model 2) t-value Coefficient (Model 3) t-value \\
\hline LNSIZE & -0.0009 & -0.1323 & -0.0011 & -0.1868 & $\mathrm{~N} / \mathrm{A}$ & $\mathrm{N} / \mathrm{A}$ \\
DEBT & 0.0726 & 1.6162 & $0.0739^{*}$ & 1.8049 & $0.0754^{*}$ & 1.9247 \\
ROE & 0.1648 & 1.6041 & 0.1662 & 1.6883 & $0.1661^{*}$ & 1.7319 \\
DILUTE & 0.0028 & 0.0801 & $\mathrm{~N} / \mathrm{A}$ & $\mathrm{N} / \mathrm{A}$ & $\mathrm{N} / \mathrm{A}$ & $\mathrm{N} / \mathrm{A}$
\end{tabular}




\begin{tabular}{ccccccc} 
OBJECITVE & $-0.0309^{*}$ & -2.0464 & $-0.0311^{* *}$ & -2.1485 & $-0.0302^{* *}$ & -2.2715 \\
C & $-0.0729^{*}$ & -1.7908 & $-0.0720^{*}$ & -1.8984 & $-0.0778^{* * *}$ & -3.7470 \\
R2 & 0.5127 & & 0.5126 & & 0.5116 & \\
Adjusted R2 & 0.3694 & & 0.4042 & & 0.4345 & \\
F-value & 3.5778 & & 4.7319 & & 6.6345 & \\
\hline
\end{tabular}

Model 3 shows that the asset-liability ratio DEBT is significantly positively correlated with the announcement effect of the public issuance. The coefficient is 0.07 , that is, for every 1 percentage point increase in the assetliability ratio, the cumulative abnormal income in the event window is increased by 0.07 percentage points. This is in line with the research hypothesis, indicating that high financial leverage is accepted by the market as a signal that the company's operating conditions are good. The ROE of net assets is significantly positively correlated with the announcement effect. The coefficient is 0.16 , that is, for every 1 percentage point increase in the net asset profit rate, the cumulative abnormal income in the event window is increased by 0.16 percentage points. This shows that the market is very valued for the company's profitability, making the coefficient of ROE higher. The regression results are consistent with the research hypothesis. The negative correlation between the use of raised funds OBJECTIVE and the announcement effect is very significant. For companies that intend to "circle money" through additional issuance (at this time OBJECTIVE takes 1), the market expresses dissatisfaction through the negative announcement effect. The results of the study show that the other conditions remain unchanged in the event window, and the "circle money" listed companies are on average 0.03 lower than the cumulative abnormal returns of listed companies that intend not to "circle money". This is in line with the research hypothesis, indicating that public infrastructure listed companies also have the motive of "circle money", while the market "votes with the feet" to respond with negative announcement effects.

The company size LNSIZE did not pass the $t$ test. The reason is mainly because the sample company selected in this study has a small gap. The average LNSIZE is 4.59, the median is 4.53 , and only one company has a LNSIZE of 7 or above (the market value exceeds 100 billion yuan). The correlation between LNSIZE and CAR $(-1,1)$ is only 0.07 . Due to the number of samples, it is not possible to further widen the differences between the samples. The hypothesis proposed in this paper will be confirmed after the number of sample companies increases in the future. The additional issuance ratio DILUTE did not pass the $t$ test, either. Through the analysis of the proportion of SEOs, it is found that the proportion of SEOs is generally low, the largest is not more than $45 \%$, the average is $21 \%$, and the median is $17 \%$. The sample has a small proportion of SEOs, and the market's response to it is not obvious compared with other factors. The correlation between DILUTE and CAR $(-1,1)$ is only 0.05 . Another possible reason is that the proportion is small, so that the dilution effect on stock value caused by SEOs is also small. If the company's profitability is strong and the funds raised are properly used, the return of future investment projects can compensate for the short-term dilution effect. Therefore, the proportion of SEOs is not a significant factor affecting the effect of the announcement.

\section{Conclusion}

By building a multivariate regression model, this study analyzed the influence factors from the perspective of the company's fundamentals and the characteristics of refinancing, and found that the company's fundamentals had same impact on the announcement effect. Return on equity, net profit margin and debt-to-equity ratio are all positively related to the accumulated abnormal return. The market pays more attention to the profitability when talking about SEOs. As to the characteristics of refinancing, the dilute ratio and the relative issuing scale have little impact on the announcement effect but the market does concern about the purpose of fund-raising.

\section{References}

1. Jensen, M. C., Meckling, W. H. (1976). Theory of the firm: Managerial behavior, agency costs and ownership structure. Journal of financial economics, 3(4), 305-360.

2. Ross, S. A. (1977). The determination of financial structure: the incentive-signalling approach. The bell journal of economics, 23-40.

3. Myers, S. C., Majluf, N. S. (1984). Corporate financing and investment decisions when firms have information that investors do not have. Journal of financial economics, 13(2), 187-221.

4. Asquith, P., Mullins Jr, D. W. (1986). Equity issues and offering dilution. Journal of financial economics, 15(1-2), 61-89.

5. Masulis, R. W., Korwar, A. N. (1986). Seasoned equity offerings: An empirical investigation. Journal of financial economics, 15(1-2), 91-118.

6. Sant, R., Ferris, S. P. (1994). Seasoned Equity Offerings: The Case of All-Equity Firms. Journal of Business Finance \& Accounting, 21(3), 429-444.

7. Booth, L., Chang, B. (2011). Information asymmetry, dividend status, and seo announcement-day returns. Journal of Financial Research, 34(1), 155-177.

8. Chaudhuri, R., Seo, H. (2012). An agency theory explanation of SEO underperformance: Evidence from dual-class firms. Journal of International Financial Markets, Institutions and Money, 22(3), 575-588.

9. Kato, H. K., Suzuki, K. (2012). Does divergence of opinion affect stock returns? Evidence from Japanese SEOs. Evidence from Japanese SEOs (November 10, 2012).

10. Scholes, M. S. (1972). The market for securities: Substitution versus price pressure and the effects of information on share prices. Journal of Business, 45(2), 179. 